\title{
NOMENCLATURAL CHANGES IN NOLANA (NOLANEAE, SOLANACEAE)
}

\section{CAMBIOS NOMENCLATURALES EN NOLANA (NOLANEAE, SOLANACEAE)}

\author{
Michael O. Dillon \\ Botany Department, The Field Museum, 1400 South Lake Shore Drive, Chicago, IL 60605 USA \\ mdillon@fieldmuseum.org
}

\begin{abstract}
RESUMEN
Una reciente revisión del material tipo que se encuentra depositado en el Museo Nacional de Historia Natural (SGO) ha requerido la transferencia de Alona patula Phil. a Nolana [N. patula (Phil.) Mesa ex M.O.Dillon], y una re-evaluación en el concepto de las especies. Nolana flaccida (Phil.) I.M.Johnst. se coloca como sinónimo de N. sphaerophylla (Phil.) Mesa ex M.O.Dillon, y el taxón previamente reconocido como N. flaccida es denominado aquí N. patula. Se proporciona además una nueva combinación junto con un análisis de los conceptos de taxonomía de las especies implicadas.
\end{abstract}

The rules and regulations concerning plant nomenclature are recorded in the International Code of Botanical Nomenclature (ICBN); the present edition is the Vienna Code (McNeill et al. 2006), based on the decisions of the XVII IBC at Vienna 2005. That code states that on or after 1 January 1953 , a new combination based on a previously and validly published name is not validly published unless its basionym is clearly indicated and a full and direct reference given to its author and place of valid publication, with page or plate reference and date (Art. 33.5 and 33.7). Further, on or after 1 January 2007, a new combination is not validly published unless its basionym or replaced synonym is cited. This paper provides a valid combination in Nolana L.f. for Alona patula Phil., a species transferred to Nolana by Mesa (1997), but not validly published due to omission of necessary data in the citation.

\section{BACKGROUND}

In 1860, R. A. Philippi published a series of new species, including Alona sphaerophylla Phil. (F1. Atacam. 44. 1860) based upon one of his collections made near Las Animas [Región II (Antofagasta)] during his 1853-54 expedition to the Atacama
Desert. Ivan M. Johnston (1929, p. 107) placed that species into synonymy of Bargemontia clavata (Miers) I.M.Johnst., a species he later reduced to the synonymy of Nolana divaricata I.M.Johnst. (Johnston 1936, p. 65). In 1895, R.A. Philippi described additional Alona species, including Alona flaccida Phil. from a collection by San Román near Salado [Región II (Antofagasta)], and Alona patula Phil. from another collection by San Román near Juncal [Región III (Atacama)]. Johnston (1929) transferred A. flaccida to Bargemontia and placed A. patula into synonymy of that species. This established priority of the epithet 'flaccida' over 'patula' when the two names were considered synonymous (Art. 11.5). Later, Johnston (1936) transferred B. flaccida (Phil.) I.M.Johnst. to Nolana and listed A. patula as a synonym of that taxon. Johnston (1936) accepted N. flaccida (Phil.) I.M.Johnst. as the correct name for a pale green shrub 1.5-3 dm tall and 10-20 dm broad, growing on the sandy floor of the quebrada-mouth at Caleta de Pan de Azúcar (e.g., Johnston 5834, GH). The plant has glabrous stems and leaves, although occasionally a very few simple hairs are to be found on the calyces and growing parts of the stems, and conspicuous pale lilac corollas. 
Mesa (1981) placed Alona flaccida, A. patula, and $A$. sphaerophylla Phil. into synonymy of his Nolana leptophylla (Miers) I.M.Johnst. ssp. mollis (Phil.) Mesa; however, in 1997, he re-visited the group, removed the three names from synoymy and, recognizing two taxa at the rank of species, published combinations in Nolana for the names A. patula and A. sphaerophylla. Mesa failed to provide full and direct references to the basionyms in Alona, as required by the Vienna Code (Art. 33.4), therefore his proposed combinations were not validly published. Moreover, Mesa incorrectly treated $N$. flaccida, the name which had priority, as a synonym of $N$. patula.

When I began my investigations in Nolana, I initially accepted Johnston's application of the name $N$. flaccida, assuming that $N$. patula was indeed a synonym. A superficial examination of the type material of Alona flaccida (lectotype, SGO 042659) in 2000, showed it to be lacking flowers or fruits, and type material of A. patula (SGO 042657) was deemed to be conspecific.

Type material of Alona sphaerophylla was examined (SGO 055082) in the same year. It appeared to be distinct and subsequent field study in the region of the type locality confirmed the taxonomic validity of the species. It had a combination of characters not found in other species known to the author, including one notable character, its small, nearly oval leaves, 3-5 mm long and cuneate petioles and 3-5 trichomes projecting laterally. Molecular studies (Dillon et al. 2007; Tu et al. 2008) also confirmed the taxonomic distinctness of this species; therefore, a combination in Nolana, N. sphaerophylla, was published by Dillon (2007). A re-examination of the lectotype of Alona flaccida in June 2009, revealed that it shares the unique leaf trichome character with $N$. sphaerophylla (Phil.) Mesa ex M.O.Dillon, that the specimen must be considered conspecific with the type of $N$. sphaerophylla, and that the two names are, therefore, synonymous. Since the name Alona sphaerophylla (1860) has priority over A. flaccida (1895), the basionym of Nolana flaccida, the correct name for the taxon is $N$. sphaerophylla. Aldo Mesa had made the same observations which were discussed in an unpublished manuscript.

This discovery leaves the taxon to which the type of Alona patula belongs without a name in Nolana. Mesa's failure, in 1997, to provide a full and complete reference to the basionym means that the combination Nolana patula is yet to be published. That error is corrected here and the necessary information is provided for a validly published transfer.

\section{TAXONOMY}

Nolana patula (Phil.) Mesa ex M.O. Dillon, comb. nov.

Basionym: Alona patula Phil., Anales Univ. Chile 91. 39. 1895. TYPE: Chile. Región III (Atacama). Juncal, 1884-85, San Román s.n. (lectotype, SGO 042657; isolectotype, SGO 055080).

\section{ACKNOWLEDGMENTS}

The author thanks the staff at the Museo Nacional de Historia Natural for facilitating access to types. Fred Barrie is acknowledged for reviewing the manuscript. The paper benefited from comments in the review process. Ongoing research has been supported by grants from National Science Foundation (DEB 0415573, DEB 9801297, DEB 8513205) and the Bankard Latin American Research Fund (The Field Museum).

\section{REFERENCES}

Dillon, M.O. 2007. Nolana sphaerophylla (Phil.) Mesa ex M.O.Dillon, En: F.O. Zuloaga, O. Morrone \& M.J. Belgrano, Novedades taxonómicas y nomenclaturales para la flora del Cono Sur de Sudamérica / Taxonomical and nomenclatural novelties for the Vascular Flora of the Southern Cone of South America. Darwiniana 45(2): 236-241.

Dillon, M.O., T. Tu, A. Soejima, T. Yi, Z. Nie, A. Tye \& J.WEN. 2007. Phylogeny of Nolana (SolanoideaeSolanaceae) inferred from granule-bound starch synthase I (GBSSI or Waxy) marker. Taxon 56: $1000-1011$.

Johnston, I.M. 1929. Papers on the flora of northern Chile. Contribution of the Gray Herbarium 4(85):1-180.

Johnston, I.M. 1936. A study of the Nolanaceae. Proceedings of the American Academy of Arts and Sciences 112: 1-83.

Mesa-M., A. 1981. Nolanaceae. Flora Neotropica Monograph 26: 1-197.

Mesa-M., A. 1997. Nolanáceae de Distribución ChilenoPeruana: su status taxonómico. Boletín del Museo Nacional de Historia Natural de Chile 46: 23-32. 
Gayana Bot. 66(2), 2009

McNeill, J., F.R. Barrie, H.M. Burdet, V. Demoulin, D.L. Hawksworth, K. Marhold, D.H. Nicolson, J. Prado, P.C. Silva, J.E. Skog, J.H. Wiersema \& N.J. TuRLAND. 2006. International Code of Botanical Nomenclature (Vienna Code). Regnum Vegetabile 146. A.R.G. Gantner, Verlag KG. VIII + 568 pp.
Tu, T., M.O. Dillon, H. Sun \& J. Wen. 2008. Phylogeny of Nolana (Solanaceae) of the Atacama and Peruvian Deserts inferred from sequences of four chloroplast markers and the nuclear LEAFY second intron. Molecular Biology and Evolution 49: 561-573.

Recibido: 09.07.09

Aceptado: 30.09.09 